\title{
ПСИХОЛОГІЧНИЙ СУПРОВІД ОСВІТИ В УМОВАХ ПАНДЕМІї
}

\author{
Наукова доповідь на веб-конференції «Учені НАПН України - українським \\ вчителям», 27 серпня 2020 р.
}

https://doi.org/10.37472/2707-305X-2020-2-2-12-2

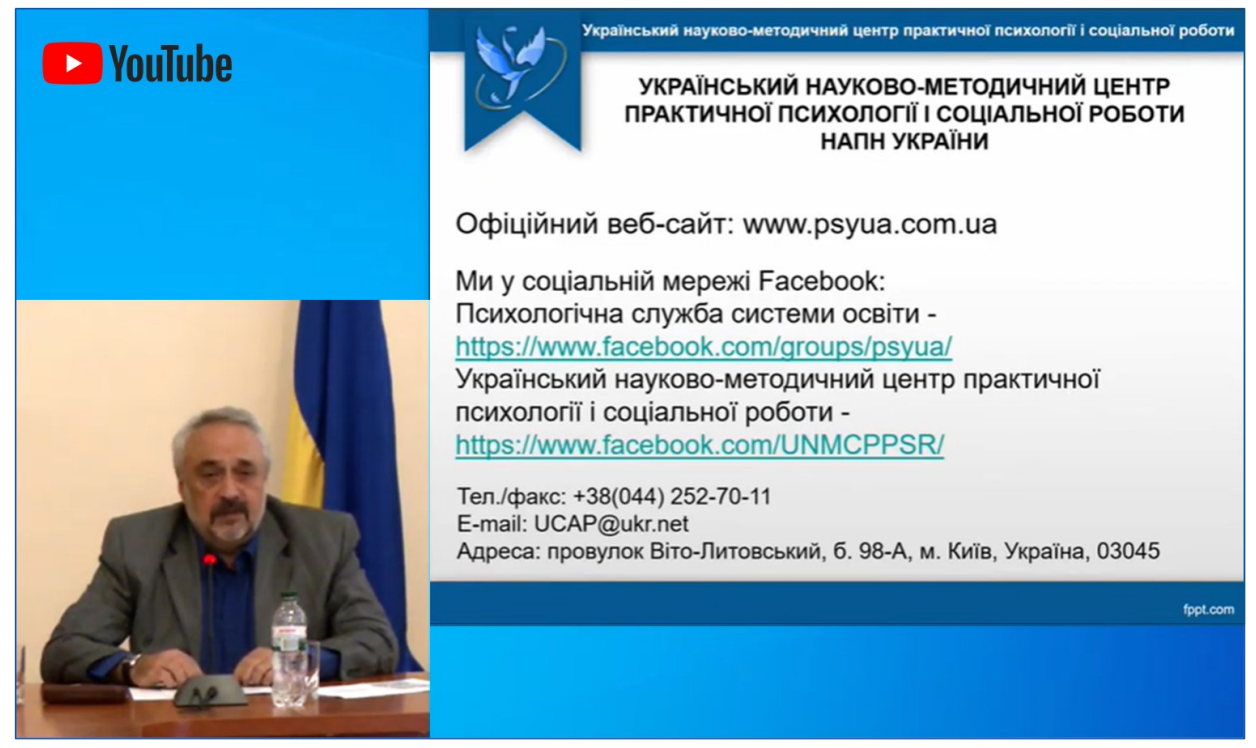

\section{ПАНОК}

\section{Віталій Григорович} доктор психологічних наук, профресор, членкореспондент НАПН України, директор Українського науковометодичного чентру практичної психології і соціальної роботи, Національна академія педагогічних наук України, м. Київ, Україна

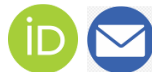

\section{МАРУXIHА Ірина Володимирівна} науковий співробітник лабораторії прикладної психології освіти Українського науково-методичного чентру практичної психології і соціальної роботи, Начіональна академія педагогічних наук України, м. Київ, Україна

\begin{abstract}
РОМАНОВСЬКА Діана Дорімедонтівна кандидат психологічних наук, старший науковий співробітник лабораторії прикладної психології освіти Українського науково-методичного центру практичної психології і соціальної роботи, Національна академія педагогічних наук України, м. Київ, Україна
\end{abstract}
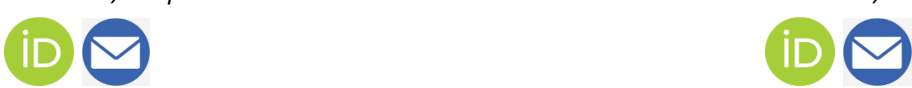

Анотація. Пандемія COVID-19 має істотні негативні соціально-психологічні наслідки. Заходи з протидії пандемії - масковий режим, соціальне дистанціювання, особливості перебування учнів і вчителів у закладі освіти, необхідність самоізоляції інфікованих тощо - можуть негативно впливати на організацію освітнього прочесу. Такий режим роботи закладу освіти ускладнює працю представників психологічної служби практичних психологів і соціальних педагогів. В умовах карантину в окремих закладах освіти запроваджується дистанційне або змішане навчання, що породжує низку ускладнень. Для учнів: немає зовнішнього контролю (або його послаблено) за виконанням навчальних завдань; складно самоорганізуватися і планувати режим навчальної роботи і відпочинку; обмежено соціальні контакти з однолітками. Для вчителів: необхідно змінювати плани і навчальні програми з урахуванням застосування телекомунікаційних технологій; у значної частини педагогів низький рівень навичок користування ІТ-технологіями; необхідно поєднувати професійну діяльність із приватним життям і змінювати усталений ритм життя. Діяльність працівників психологічної служби в умовах пандемії має здійснюватися відповідно до умов карантину в конкретному закладі освіти. За умови дотримання карантинних заходів зменшується кількість групових занять, а деякі здійснюються онлайн. Індивідуальне консультування та інші індивідуальні форми роботи можуть відбуватися як онлайн, так і у безпосередній взаємодії. Основними завданнями роботи є: зменшення психоемоційного напруження; підвищення стресостійкості (резильєнтності); профрілактика дискримінації і стигматизації інфікованих; формування позитивної життєвої перспективи.

Ключові слова: пандемія COVID-19; психологічна служба; система освіти; психічне здоров'я; емочійне благополуччя; дискримінація; стигматизачія; методи надання психологічної допомоги. 
Навчальний 2020/2021 рік істотно відрізняється від попередніх. Насамперед тим, що учасники освітнього процесу змушені докорінно змінювати і форми та методи навчання, і форми міжособистісного спілкування. Причина цього - карантинні заходи, зумовлені поширенням пандемії COVID-19. Тому діяльність працівників психологічної служби системи освіти - практичних психологів, соціальних педагогів і методистів навчально-методичних центрів психологічної служби - також потребує суттєвих змін як у змістовому, так і в організаційно-методичному плані.

Попри деяку розгубленість, освітяни зараз активно працюють над опануванням нових форм роботи з учнями та іншими учасниками освітнього процесу. Передусім опановуються дистанційні форми освітньої діяльності та надання психологічної і соціально-педагогічної допомоги.

У зв'язку з можливим запровадженням таких форм навчання набуває актуальності і робота 3 формування стійкості до стресу в учасників освітнього процесу. Важливість різноманітних заходів обумовлена і вимогами, що їх висуває МОЗ України (носіння масок, застосування антисептиків, соціальне дистанціювання, розклеювання листівок про коронавірус тощо). Усе це може посилити тривожні настрої в учасників освітнього процесу. Отже, маємо визнати: діяльність системи освіти загалом і працівників психологічної служби відбувається в умовах надзвичайної ситуації (Горленко та ін., 2017; Панок, 2017; Панок, 2020b; Рыбалка, \& Самодрин, 2020; Furman et al., 2020).

Відповідно до українського законодавства надзвичайна ситуація - це обстановка на окремій території чи суб'єкті господарювання на ній або водному об'єкті, яка характеризується порушенням нормальних умов життєдіяльності населення, спричинена катастрофою, аварією, пожежею, стихійним лихом, епідемією, епізоотією, епіфітотією, застосуванням засобів ураження або іншою небезпечною подією, що призвела (може призвести) до виникнення загрози життю або здоров'ю населення, великої кількості загиблих і постраждалих, завдання значних матеріальних збитків, а також до неможливості проживання населення на такій території чи об'єкті, провадження на ній господарської діяльності (Панок, Чаплак, \& Андрєєва, 2019).

Соціально-психологічні та індивідуальнопсихологічні наслідки надзвичайних ситуацій, зазвичай, бувають негативними - паніка, немотивована агресія, обмеження соціальних контак- тів, депресія, недовіра та ін. Усе це відноситься до непродуктивних форм поведінки в такій ситуації, що власне тільки посилюють негативні процеси (Панок, 2020; Рыбалка, \& Самодрин, 2020; Furman et al., 2020).

Науковці та практики вже напрацювали певний досвід надання психологічної допомоги особистості, яка пережила надзвичайну ситуацію. Водночас нині Україна, як і багато інших країн, зіткнулася з новою глобальною катастрофою пандемією COVID-19. 3 урахуванням цього та для запобігання поширенню інфекції в Україні 3 12 березня 2020 р. було оголошено загальнонаціональний карантин, а з 25 березня 2020 р. надзвичайну ситуацію.

Основні психологічні проблеми пандемії та загрози зараження коронавірусом COVID-19 полягають передусім у:

1) поширенні паніки та панічних настроїв, тривоги та страхів. Тривога і страх у період пандемії - нормальна реакція на «ненормальну» проблему. У такій ситуації люди часто видають гіпертрофовану «реакцію адаптації» - починають нав'язливо дивитися новини, читати матеріали про захворювання, обговорювати їх із рідними та знайомими, малювати драматичні картини майбутнього;

2) вивільненні часу при соціальній ізоляції чи самоізоляції і, як наслідок, фрустрація (блокування) головних потреб особистості - потреби у спілкуванні та соціальних контактах.

Найбільш відомими психологічними ознаками карантину як форми ізоляції $€$ сенсорна депривація, монотонія, одноманітність інтер'єру приміщення, дозвільний характер, гіподинамія, нудьга, похідними від яких може стати певний душевний дискомфорт і навіть депресія (Рыбалка, \& Самодрин, 2020; Sirko et al., 2020).

Як свідчить практика, поведінка людей у ситуації пандемії демонструє різноманітні, іноді протилежні, підходи і види. їх ставлення до пандемії може бути активним чи пасивним, оптимістичним чи песимістичним, гуманістичним або байдужим, вони виявлять при цьому позити вне чи негативне мислення тощо (Рыбалка, \& Самодрин, 2020; Панок, 2020b).

Водночас стрес, страх, панічні настрої, прояви агресії, які охопили вже мільйони та десятки мільйонів мешканців різних країн світу і України в ситуації пандемії, свідчать про гостру потребу в наданні професійної психологічної допомоги дітям і дорослим. 
Усе зазначене вище посилює роботу спеціаліста психологічної служби щодо збереження психологічного і соціального здоров'я учасників освітнього процесу в період карантину, який встановлено в країні у зв'язку з поширенням загрози захворювання коронавірусом.

На нашу думку, основною метою роботи спеціаліста в подоланні негативних соціальнопсихологічних наслідків в умовах карантинних заходів є актуалізація адаптивних і компенсаторних ресурсів особистості, стабілізація емоційної сфери, мобілізація психологічного потенціалу учасників освітнього процесу, формування стійкості до стресу.

Основні завдання фахівців психологічної служби у цей період:

- формування конструктивних способів вирішення складних життєвих ситуацій та адаптивних копінг-стратегій у всіх учасників освітнього процесу;

- стабілізація емоційної сфери особистості, формування позитивної життєвої перспективи;

- активізація процесів самопізнання, самосприйняття, саморегуляції і самоконтролю, побудова позитивного образу майбутнього;

- формування психосоціальної стійкості до стресу;

- профілактика дискримінації і стигматизації людей, які хворіють або перехворіли;

- надання своєчасної психологічної допомоги жертвам булінгу і цькувань;

- запобігання емоційному вигоранню у батьків і педагогів;

- підвищення адаптаційних можливостей учителя до нових умов організації освітнього процесу;

- здійснення посередництва між закладом освіти, сім'ями та територіальними місцевими громадами щодо вирішення та попередження міжособистісних конфліктів, домашнього насильства тощо (Рыбалка, \& Самодрин, 2020).

Необхідно наголосити, що відчуття психологічної рівноваги, захищеності та безпеки, які $€$ основою стану емоційного благополуччя, виникають у дитини передусім завдяки спілкуванню з дорослими, і перш за все, з батьками.

Головне запитання, яке виникає у батьків у цей період, можна сформулювати так: «як поєднати роботу, побут та батьківство і не вичерпати при цьому власні внутрішні емоційні ресурси?» Таке питання обумовлено низкою проблем, 3 якими зіткнулися батьки, зокрема, ізоляція, постійне перебування в обмеженому просторі протягом тривалого часу з іншими членами сім'ї разом із іншими стресовими факторами неминуче призводить до конфліктів у родині. Вчені довели, що вимушена індивідуальна чи групова ізоляція негативно впливає на самопочуття та емоційний стан людини. При цьому виникає така послідовність психологічних реакцій:

- Сповільнення ритму життя під час карантину та необхідність перебудови життєвих планів.

- Переформатування робочого графіку/ режиму життєдіяльності (для деяких батьків робота перейшла в дистанційний формат, в інших - тимчасово призупинена, що змусило звільнитися або піти у відпустку без збереження заробітної плати).

- Поєднання дистанційного виконання своїх посадових обов'язків із виконанням домашніх. Зробити це непросто, якщо поруч постійно знаходиться дитина (діти), яка (які) потребує (потребують) уваги.

- Дистанційне навчання дітей. Батьки змушені брати на себе певні функції вчителів щодо організації освітньої діяльності дитини в умовах онлайннавчання.

Якщо говорити про педагогів, то в ситуації вимушеної ізоляції учителю доводиться одночасно перебувати у двох ролях: вчителя і батька/ матері. А тому до тих проблем, що виникають у педагога як у батька/матері, додаються суто специфічні, зумовлені професійною діяльністю:

1. Зміна режиму освіти - перехід на дистанційне навчання.

Дистанційне навчання до карантину знаходилося у стані незатребуваності в масштабах країни і поволі еволюціонувало. Зараз ситуація змінилася, і вчителю необхідно оперативно перебудуватися, змінити звичні форми і методи роботи, адже без прямої комунікації з учнями необхідно готувати більше карт, анімацій, експериментів. Це посилює напруження, що негативно позначається на психоемоційному та фізичному стані вчителя.

2. Часові обмеження в оволодінні сучасними освітніми ресурсами, які $€$ необхідною умовою навчання в дистанційному режимі. До цього слід додати відчуття невпевненості у власних можливостях і здібностях як у засвоєнні інформаційних технологій, так і у розробленні власної методики навчання предмета з використанням інформаційно-комунікаційних технологій.

3. Зниження рівня працездатності в умовах самоізоляції та обмеженої рухової активності. 
Відсутність живого зв'язку з учнем, як наслідок, відсутність спокою та морального задоволення від роботи.

У випадку з пандемією найскладніше адаптуватися дітям, адже вони опинилися в ситуації, яка не відповідає їх віку. Вони відчувають загальну тривогу від невизначеності, напруження батьків, зміни звичного режиму та обмежень.

3 якими ж труднощами за цих умов стикаються діти?

1. Труднощі з самоорганізацією, і не тільки при організації освітньої діяльності.

Більшість дітей погано відчувають час і не вміють його планувати. Крім того, під час карантину важливими $є$ такі якості особистості, як дисциплінованість та відповідальність за дотримання режиму, спостережливість, самоорганізованість, адаптивність, акуратність, аскетизм, креативність, винахідливість тощо. Зрозуміло, що ці якості формуються поступово, відповідно до віку, а тому в багатьох дітей вони або не сформовані, або сформовані недостатньо.

2. Труднощі, зумовлені переходом на дистанційне навчання, зокрема: зниження рівня працездатності, концентрації уваги, запам'ятовування, осмислення навчального матеріалу в умовах самоізоляції та обмеженої рухової активності; зменшення зосередженні під час навчання без прямого впливу вчителів у ситуації, коли «розплата» ще далеко і незрозуміло, чи взагалі буде.

3. Підвищення вразливості до соціальних ризиків, зокрема в Інтернеті. Це зумовлено тим, що значна кількість дітей і підлітків у цей час опинилися вдома без догляду дорослих, адже дехто з батьків продовжує працювати на робочих місцях у зв' язку з відсутністю умов для віддаленого (дистанційного) виконання посадових обов'язків.

4. Відсутність можливості бачитися з друзями, педагогами наживо. Як наслідок, це може призвести до того, що діти відвикають один від одного та вчителів.

Реалізувати ці завдання в умовах карантину можливо лише дистанційно з використанням соціальних мереж і вебсайтів закладів освіти. Використання соціальних мереж дає змогу збільшити кількість отримувачів тих чи інших видів психологічної допомоги, якісно змінює специфіку роботи спеціаліста. Проте в будь-якому випадку незмінним залишається дотримання спеціалістом етичних норм (для чого можна використовувати чати, месенджери, електронне листування).
Основними формами та технологіями роботи практичного психолога та соціального педагога 3 учасниками освітнього процесу можуть бути:

- консультування онлайн (з використанням програм Zoom, Skype, WhatsApp) з метою зниження можливих негативних ефектів (паніка, чутки, агресивні прояви);

- консультування за принципом «телефон довіри» через електронну пошту та оперативна допомога через соціальні мережі;

- діагностика через Інтернет з можливістю збору даних на єдиному ресурсі (наприклад, тестування через Google-форми);

- психологічна просвіта та психопрофілактика шляхом створення цікавого відеоконтенту, пря мих ефірів, вебінарів тощо;

- психологічна корекція з використанням та мобільних онлайн-тренажерів, онлайн-ігор (наприклад, для корекції та розвитку пізнавальних процесів);

- організація у дистанційній формі груп взаємопідтримки для батьків, учнів, педагогів, підви щення стресостійкості в домашніх умовах, підви щення рівня комунікацій у сім'ї.

Наголошуємо, що річне планування роботи фахівця психологічної служби здійснюється відповідно до затверджених МОН України Циклограм діяльності які, з одного боку, забезпечують виконання необхідних дій для закладів освіти усіх типів, з іншого - дають змогу врахувати специфіку закладу та запити учасників освітнього процесу (Горленко та ін., 2017; Панок, 2020а). Відповідно до епідеміологічної обстановки, яку прийнято позначати кольорами, працівники психологічної служби мають вносити відповідні корективи у планування і форми роботи.

\section{Зелена та жовта зони}

Відповідно до ст.76 Закону України «Про освіту» (2017) учасники освітнього процесу в кожному закладі мають бути забезпечені психологічним супроводом і соціально-педагогічним патронажем. Психологічна допомога або підтримка учнів та педагогів здійснюється відповідно до Положення про психологічну службу в системі освіти України та рекомендацій $\mathrm{MOH}$ України (МОН України, 2018; ІМ30, 2020).

Щоденно практичному психологу та соціальному педагогу рекомендовано здійснювати не менше чотирьох годин роботи зі здобувачами освіти, які потребують психологічного втручання: діагностичної, просвітницької, профілактичної, корекційної, консультативної - орієнтовно 
1-2 години групової роботи; 2-3 години індивідуальної роботи. У журналі практичного психолога, соціального педагога необхідно відображати щоденно 8 робочих годин (1 ставка): з яких $4-$ організаційно-методична робота.

Важливо структурувати роботу з різними категоріями дітей і учнів. Перевага надається індивідуальній формі роботи з урахуванням усіх протиепідемічних заходів і дотриманням правил особистої гігієни, тобто перед початком роботи необхідно помити руки або продезінфікувати руки антисептичним засобом, після роботи провітрити приміщення, наприкінці робочого дня здійснити санітарне прибирання. Для оптимізації роботи рекомендується складати погодинний графік проведення індивідуальних (діагностичних, просвітницьких, профілактичних, корекційних, консультаційних) занять на кілька днів наперед (у позаурочний час) та інформувати завчасно учнів, батьків і педагогів.

Групова діагностична, просвітницько-профілактична робота за програмами, рекомендованими МОН України, проводиться працівником психологічної служби з дітьми, учнями в невеликих групах в межах одного класу в позаурочний час за окремим розкладом 1 раз на тиждень, про що повідомляється вчителю і батькам онлайн (телефоном, у вайбер-групах).

Такі заняття проводять в окремих кабінетах практичного психолога (соціального педагога) або в класних кімнатах. Групові короткотривалі опитування, анкетування (5-10 хв.) щодо психоемоційного стану здобувачів освіти, скринінгу ситуацій булінгу та домашнього насильства, мікроклімату та процесів адаптації та соціалізації можна проводити в навчальних приміщеннях на початку або наприкінці уроку (за попереднім погодженням з учителем, з дотриманням правил особистої гігієни відповідно до протиепідемічних заходів).

За потреби у невідкладних заходах щодо збереження психічного здоров'я і благополуччя здобувачів освіти, нагальної психологічної допомоги у стабілізації їх психоемоційного стану, особливо у випадках: протидії психологічному насильству та булінгу; порушення депресивного спектра; підвищеного рівня тривожності та агресивності; самоушкоджувальної та суїцидальної поведінки індивідуальні заняття можна проводити в урочний час (за попереднім погодженням 3 адміністрацією, батьками та вчителями).
В окремих випадках варто застосовувати в роботі з учасниками освітнього процесу (з батьками, педагогами, здобувачами освіти) сучасні безконтактні форми соціально-психологічного супроводу: індивідуальні або групові онлайнконсультування, просвітницько-профілактичні онлайн-заняття (телефоном або за допомогою Skype чи Zoom). Рекомендується практикувати онлайн-опитування, анкетування учасників освітнього процесу з різних питань за допомогою створення Google-форми.

Звертаємо увагу на питання, які мають бути обов' язково відображені у планах роботи практичного психолога та соціального педагога: збереження психічного здоров'я та соціального благополуччя здобувачів освіти; стабілізація їх психоемоційного стану, особливо у випадках протидії психологічному насильству та булінгу, порушення депресивного спектра, підвищеного рівня тривожності та агресивності, самоушкоджувальої та суїцидальної поведінки.

Помаранчева зона

Як і в зеленій, жовтій зоні, але додатково:

Збільшується кількість годин індивідуальної роботи до 3-4-х, зменшується (до 1 години) або усувається форма групової роботи. Корекційна робота за потребою, за необхідністю. Кількість здобувачів освіти у груповій роботі зменшується відповідно до санітарних норм з використанням захисних масок (не більше 10 осіб у приміщенні). Під час групових занять застосовуються винятково індивідуальні або безконтактні вправи, завдання, технології. Впроваджується онлайн-діагностика, індивідуальні та групові онлайн-консультації, просвітницькі та профілактичні заняття онлайн.

Червона зона

Для оптимізації роботи рекомендується складати погодинний графік проведення індивідуальних (діагностичних, просвітницьких, профілактичних, консультаційних, за можливості й корекційних) онлайн-занять на кілька днів наперед (у позаурочний час) та інформувати завчасно учнів батьків. Для цього складається і оприлюднюється графік роботи фахівця психологічної служби на тиждень.

Рекомендується застосовувати онлайнопитування, анкетування учасників освітнього процесу з різних питань за допомогою створення Google-форми. Індивідуальні або групові онлайнконсультування, просвітницько-профілактичні онлайн-заняття (телефоном або за допомогою Skype чи Zoom) проводяться з учасниками освіт- 
нього процесу (батьками, педагогами, здобувачами освіти) за запитом, за потребою, за результатами діагностичних досліджень для збереження психічного здоров'я у кризовий період.

Групові просвітницько-профілактичні програми, рекомендовані МОН України, працівник психологічної служби проводить з учнями онлайн у позаурочний час за окремим розкладом 1 раз на тиждень, про що повідомляється завчасно вчителю і батькам. Усі види роботи, що проводить фахівець, мають бути відображені у відповідній документації для ведення якої передбачено окремий час у графіку роботи.

Підсумовуючи зазначене, необхідно наголосити на тому, що в сучасних умовах соціальноекономічної кризи і карантинних заходів, пов'язаних із пандемією, істотно зростає роль психологічної служби системи освіти у наданні соціальнопедагогічної і психологічної допомоги всім учасникам освітнього процесу, збереженні їхнього соціального благополуччя і психічного здоров'я та забезпеченні реалізації завдань закладів освіти.

\section{СПИСОК ВИКОРИСТАНИХ ДЖЕРЕЛ}

Горленко, В.М., Луценко, Ю.А., Острова, В.Д., Сосновенко, Н.В., \& Ткачук, І.І. (2017). Методичні рекомендації щодо впровадження ииклограм діяльності працівників психологічної служби (В.Г. Панок, ред.). Київ: УНМЦ практичної психології і соціальної роботи. https://lib.iitta.gov.ua/709623/

Закон України «Про освіту». (2017, 5 вересня). https:// zakon.rada.gov.ua/laws/show/2145-19

Інститут модернізації змісту освіти. (2020, 27 липня). Про пріоритетні напрями роботи психологічної служби у системі освіти на 2020/2021 н. p. (22.1/10-1495). https://bit.ly/3kQCt2w

Міністерство освіти і науки України. (2018, 22 травня). Про затвердження Положення про психологічну службу у системі освіти України (509). https:// zakon.rada.gov.ua/laws/show/z0885-18

Національна академія педагогічних наук України. (2020, 27 серпня). Учені НАПН України - українським вчителям [Відео]. ҮouTube. https://www.youtube.com/ watch?v=HvOGb8000Tw

Панок, В.Г. (2017). Прикладна психологія у педагогічній практиці України. Психологія і суспільство, (4), 94108. https://doi.org/10.35774/pis2017.04.094

Панок, В.Г. (2020а). Концепція психологічного супроводу освітніх реформ у діяльності психологічної служби. Вісник Національної академії педагогічних наук України, 2(1). https://doi.org/10.37472/2707-305X-2020-2-1-9-1

Панок, В.Г. (2020b). Роль практичної психології і соціальної роботи у протидії пандемічній загрозі. In В.Г. Кремень (ред.) Психологія і педагогіка у протидіі пандемії COVID-19 : Інтернет-посібник (с. 75-76). Київ: ТОВ «Юрка Любченка». https://lib.iitta.gov.ua/719827/

Панок, В.Г., Чаплак, Я.В., \& Андрєєва, Я.Ф. (2019). Основи психологічної допомоги: теорія та практика психоконсультування : навчальний посібник (В.Г. Панок, І.М. Зварич, ред.). Чернівці: Чернівецький національний університет імені Юрія Федьковича.

Рыбалка, В.В., \& Самодрин, А.П. (ред.). (2020). COVID-19 в измерениях философии, психологии и педагогики : пособие. Киев, Днепр, Кременчуг: ПП Щербатых А.В.

Furman, O., Shandruk, S., Gerasymova, E., Panok, V., Vasylkiv, O., \& Lukashuk, M. (2020). Psychological and educational support of students' self-regulation development. International Journal of Management, 11(4), 326338. https://doi.org/10.34218/IJM.11.4.2020.033

Sirko, R.I., Bezverkhnia, H.V., Zaverukha, O.Ya., Chupakhina, S.V., \& Kyrsta, N.R. (2020). Motivation to Get a Second Higher Education: Psychological and Pedagogical Aspect. International Journal of Learning, Teaching and Educational Research, 19(2), 188-202. https:// doi.org/10.26803/ijlter.19.2.11

\section{PSYCHOLOGICAL SUPPORT OF EDUCATION IN A PANDEMIC}

Scientific report at the web conference "The NAES of Ukraine Researchers to Ukrainian teachers", August 27, 2020

\section{Vitalii Panok}

DSc in Psychology, Professor, Corresponding Member of NAES of Ukraine, Director, Ukrainian Scientific and Methodological Center of Applied Psychology and Social Work, National Academy of Educational Sciences of Ukraine, Kyiv, Ukraine Iryna Marukhina

Research Fellow, Ukrainian Scientific and Methodological Center of Applied Psychology and Social Work, National Academy of Educational Sciences of Ukraine, Kyiv, Ukraine Diana Romanovska

PhD in Psychology, Senior Research Fellow of the Applied Psychology of Education Laboratory, Ukrainian Scientific and Methodological Centre of Applied Psychology and Social Work, National Academy of Educational Sciences of Ukraine, Kyiv, Ukraine

Abstract. The COVID-19 pandemic has significant negative socio-psychological consequences. Measures to combat the pandemic negatively affect the organization of the educational process - the mask regime, social distancing, the peculiarities of the stay of students and teachers in the educational institution, the need for self-isolation of the infected, etc. Such mode of operation of the educational institution significantly complicates the work of employees of the psychological service - practical psychologists and social educators.

Under quarantine conditions, distance or blended learning is introduced in some educational institutions. The transition to this form of education creates a number of complications. For students: lack of external control (or weakening of one) over the implementation of educational tasks; difficulties with self-organization and planning of the 
mode of educational work and rest; significant restriction of social contacts with peers.

For teachers: the need to change plans and curricula to take into account the need to use telecommunications technology; low level of skills of IT-technologies of a significant part of teachers; the need to combine professional activity with private life and the need to change the established rhythm of life.

The activities of psychological service workers in a pandemic should be carried out in accordance with the conditions of quarantine in a particular educational institution. Subject to quarantine measures, the number of group classes is reduced and some forms of work are carried out online. Individual counseling and other individual forms of work can be carried out both online and in direct interaction.

The main objectives of the work are: reducing psycho-emotional stress; increasing stress resistance (resilience); prevention of discrimination and stigmatization of the infected; formation of a positive life perspective.

Keywords: COVID-19 pandemic; psychological service; education system; mental health; emotional well-being; discrimination; stigmatization; methods of providing psychological assistance.

Дата публікації: 25 вересня 2020 р. 